\title{
PENGETAHUAN DAN KEPATUHAN PENERAPAN PROTOKOL KESEHATAN PADA PENGUNJUNG PRAKTIK MANDIRI BIDAN DI DESA RAJAGALUH KIDUL
}

\author{
Leni Marlina $^{1}$, Dewi Erna Marisa ${ }^{2}$ Lely Nurlaili $^{3}$ \\ 1,2,3 STIKes Mahardika, Cirebon, Indonesia,lenimn8@gmail.com
}

\begin{tabular}{l}
\hline ARTICLE INFORMATION \\
\hline Received: July, 31, 2021 \\
Revised: Agustus, 10, 2021 \\
Available online: September, 10, 2021 \\
KEYWORDS \\
\hline
\end{tabular}

Knowledge and Compliance, Health Protocols

CORRESPONDENCE

Leni Marlina

STIKes Mahardika, Indonesia

E-mail: lenimn8@gmail.com

\section{$A B S T R A C T$}

Covid-19 is an infectious disease caused by a new type of coronavirus that was discovered in 2019 and became a pandemic that occurred in countries around the world. Symptoms include fever, cough, difficulty breathing accompanied by tightness, weakness, muscle aches, diarrhea and other symptoms of respiratory disorders. The best way to prevent infection is to avoid exposure to the causative virus, comply with health protocols as an effort to prevent transmission in daily life practices. The purpose of this research is to know the level of knowledge and compliance of the application of health protocols to visitors of Private Midwife Independent Practice in Rajagaluh Kidul Village. The type or design of research used is descriptive method. In this study, researchers used purposive sampling techniques with a sample of 79 respondents. The instrument used is a questionnaire tailored to the researcher's objectives. The results found that the majority of respondents have good knowledge of health protocols as much as (57.0\%) and most visitors' compliance with the implementation of high-compliance health protocols (45.6\%). The conclusion of the end research is knowledgeable and the compliance of highly compliant visitors means there is a connection between knowledge and compliance, so knowledge has a significant influence on compliance behavior.

\begin{abstract}
A $\mathbf{B} \quad \mathbf{S}$ T $\mathbf{R}$ A $\mathbf{K}$
Covid-19 merupakan penyakit menular yang disebabkan oleh jenis coronavirus yang baru ditemukan pada tahun 2019 dan menjadi sebuah pandemi yang terjadi di Negara seluruh dunia. Gejala-gejalanya adalah demam, batuk, sulit bernafas disertai dengan sesak, lemas, nyeri otot, diare dan gejala gangguan nafas lainnya. Cara terbaik untuk mencegah infeksi adalah dengan menghindari terpapar virus penyebab, menaati protokol kesehatan sebagai upaya pencegahan penularan dalam praktik kehidupan sehari-hari. Tujuan penelitian ini untuk mengetahui tingkat pengetahuan dan kepatuhan penerapan protokol kesehatan pada pengunjung Praktik Mandiri Bidan Swasta Di Desa Rajagaluh Kidul. Jenis atau desain penelitian yang digunakan adalah metode deskriptif. Dalam penelitian ini, peneliti menggunakan teknik pengambilan sampel secara purposive sampling dengan sample sebanyak 79 responden. Instrument yang digunakan adalah kuesioner yang disesuaikan dengan tujuan peneliti. Hasil penelitian didapatkan bahwa mayoritas responden memiliki pengetahuan yang baik tentang protokol kesehatan sebanyak $(57,0 \%)$ dan sebagian besar kepatuhan pengunjung terhadap penerapan protokol kesehatan berkepatuhan tinggi sebanyak $(45,6 \%)$. Kesimpulan hasil penelitian pengujung berpengetahuan baik dan kepatuhan pengunjung berkepatuhan tinggi artinya ada hubungannya antara pengetahuan dengan kepatuhan, jadi pengetahuan memberikan pengaruh yang signifikan terhadap perilaku kepatuhan
\end{abstract}




\section{PENDAHULUAN}

Covid-19 merupakan penyakit menular yang disebabkan oleh jenis coronavirus yang baru ditemukan pada tahun 2019 dan menjadi sebuah pandemi yang terjadi di Negara seluruh dunia (WHO, 2020). Gejala-gejalanya adalah demam, batuk, sulit bernafas disertai dengan sesak, lemas, nyeri otot, diare dan gejala gangguan nafas lainnya. Cara terbaik untuk mencegah infeksi adalah dengan menghindari terpapar virus penyebab, menaati protokol kesehatan sebagai upaya pencegahan penularan dalam praktik kehidupan sehari-hari (POGI, 2020).

Pada tanggal 11 Maret 2020 COVID-19 ditetapkan menjadi pandemi dan pada tanggal 30 Januari 2020 kejadian COVID-19 ini sebagai Kedaruratan Kesehatan Masyarakat yang Meresahkan Dunia (KKMMD)/Public Health Emergency Of International Concern (PHEIC) yang ditetapkan oleh WHO (Kemenkes, 2020). Berdasarkan data tanggal 14 Februari 2020, angka mortalitas dari seluruh dunia sebesar $2,1 \%$, secara khusus di kota Wuhan sebesar 4,9\% dan provinsi Hubei sebesar 3,1\%. Untuk di Indonesia tanggal 14 Maret 2020 sebanyak 96 kasus yang terkonfirmasi COVID-19 dengan jumlah kematian 6 orang dan menjadi negara ke 65 yang positif konfirmasi COVID-19. Secara keseluruhan tingkat mortalitas dari COVID-19 masih lebih kecil jika dibandingkan dengan kejadian Coronavirus tipe lain yaitu Severe Acute Respiratory Syndrome-coronavirus (SARSCoV) dan Middle East Respiratory Syndromecoronavirus (MERS-CoV) masing-masing sebesar 10\% dan 40\% (POGI, 2020).

Berdasarkan laporan WHO, pada tanggal 30 agustus 2020, terdapat 24.854.140 kasus konfirmasi Covid-19 diseluruh dunia dengan 838.924 kematian (CFR 3,4\%). Wilayah Amerika dengan 13.138.912 kasus yang terbanyak terkonfirmasi. Selanjutnya wilayah Eropa dengan 4.205.708 kasus, wilayah Asia Tenggara dengan 4.073.148 kasus, wilayah Mediterania Timur dengan 1.903.547 kasus, wilayah Afrika dengan 1.044.513 kasus, dan wilayah Pasifik Barat dengan 487.571 kasus (World Health Organization, 2020). Kasus konfirmasi Covid-19 di Indonesia masih terus bertambah. Berdasarkan laporan Kemenkes RI, pada tanggal 30 Agustus 2020 tercatat 172.053 kasus konfirmasi dengan angka kematian 7343 (CFR 4,3\%). DKI Jakarta memiliki kasus terkonfirmasi kumulatif terbanyak, yaitu 39.037 kasus. Nusa Tenggara Timur merupakan daaerah dengan kasus kumulatif tersedikit yaitu 177 kasus (Kemenkes RI, 2020).

Kasus konfirmasi Covid-19 di Provinsi Jawa Barat berdasarkan Pusat Informasi Dan Koordinasi Covid19 Provinsi Jawa Barat (PIKOBAR) pada tanggal 14 Februari 2021, menunjukan jumlah yang terkonfirmasi yaitu 174.121 kasus, untuk jumlah yang isolasi atau dalam perawatan yaitu 26.155 kasus, jumlah sembuh ada 145.857 orang dan untuk jumlah meninggalnya yaitu ada 2.109 kasus (PIKOBAR, 2021). Kasus konfirmasi Covid-19 di Kabupaten Majalengka berdasarkan Pusat Informasi Dan Koordinasi Covid-19 Kabupaten Majalengka (PIKOM) pada tanggal 3 Februari 2021, menunjukan jumlah terkonfirmasi yaitu 1496 kasus, untuk jumlah yang positifnya yaitu 135 kasus, jumlah sembuh ada 1219 kasus dan untuk jumlah meninggalnya ada 143 kasus (PIKOM, 2021).

Permasalahan yang perlu diperhatikan dalam kesuksesan program-program kesehatan untuk menurunkan jumlah angka morbiditas dan mortalitas di tengah pandemi COVID-19 khususnya pada kesehatan ibu dan anak pelayanan kebidanan dimasa pandemi COVID19 banyak hal yang perlu adanya penyesuaian pelayanan sesuai dengan protokol kesehatan (Kemenkes RI, 2020). Upaya preventif dalam protokol kesehatan yang diterapkan masyarakat dalam memutus mata rantai penularan Covid19 pada masa New Normal yaitu dengan membiasakan diri memakai masker, mencuci tangan pakai sabun (hand sanitanizer), menjaga jarak (social distancing), menjauhi keramaian dan menghindari berpergian keluar daerah, 
terutama daerah-daerah yang sudah dinyatakan zona merah (Hamdani, 2020).

Untuk lokasi penelitian disini yaitu di satu Praktik Mandiri Bidan Desa Rajagaluh Kidul melainkan tidak menyebutkan nama Praktik Mandiri Bidannya karena menjaga kerahasiaan Praktik Mandiri Bidan Tersebut.

Tujuan dari penelitian ini untuk mengetahui tingkat pengetahuan dan kepatuhan penerapan protokol kesehatan pada pengunjung Praktik Mandiri Bidan Swasta Di Desa Rajagaluh Kidul.

\section{METODE}

Jenis penelitian ini menggunakan metode deskriptif. Variabel yang diteliti yaitu pengetahuan dan kepatuhan penerapan protokol kesehatan pada pengunjung.. Populasi dalam penelitian ini seluruh pengunjung Praktik Mandiri Bidan Swasta Di Desa Rajagaluh Kidul, jumlah sampel dalam penelitian ini yaitu 79 pengunjung Praktik Mandiri Bidan. Teknik pengambilan sampel yaitu menggunakan purposive sampling. Instrumen berupa kuesioner yang dibuat oleh peneliti terdiri dari 20 pertanyaan yang akan diolah dengan skala Guttman jika jawaban benar bernilai 1 dan jika jawaban salah bernilai 0 yang kemudian dianalisa secara univariat.

Penelitian dilaksanakan di Praktik Mandiri Bidan Swasta Di Desa Rajagaluh Kidul yang dilakukan pada tanggal 05 Juni 2021 s.d 09 Juni 2021.

\section{HASIL PENELITIAN}

Distribusi frekuensi Pengetahuan Dan Kepatuhan Penerapan Protokol Kesehatan Pada Pengunjung Praktik Mandiri Bidan Swasta Di Desa Rajagaluh Kidul.

Tabel 1 Distribusi Frekuensi Pengetahuan Tentang Protokol Kesehatan

\begin{tabular}{lcc}
\hline Pengetahuan & Frekuensi & Presentase\% \\
\hline Baik & 45 & $57,0 \%$ \\
Cukup & 22 & $27,8 \%$ \\
Kurang & 12 & $15,2 \%$ \\
\hline Total & $\mathbf{7 9}$ & $\mathbf{1 0 0 \%}$ \\
\hline
\end{tabular}

Berdasarkan tabel 1 di atas menunjukan bahwa pengetahuan pengunjung dengan kategori baik sebanyak 45 responden dengan presentase ( 57,0\%), kategori cukup sebanyak 22 responden dengan presentase $(27,8 \%)$, dan kategori kurang sebanyak 12 responden dengan presetase $(15,2 \%)$.

Tabel 2 Distribusi Frekuensi Kepatuhan Penerapan Protokol Kesehatan

\begin{tabular}{lcc}
\hline Kepatuhan & Frekuensi & Presentase\% \\
\hline Tinggi & 36 & $45,6 \%$ \\
Sedang & 25 & $31,6 \%$ \\
Rendah & 18 & $22,8 \%$ \\
\hline Total & $\mathbf{7 9}$ & $\mathbf{1 0 0 \%}$ \\
\hline
\end{tabular}

Berdasarkan tabel 2 di atas menunjukan bahwa kepatuhan pengunjung dengan kategori tinggi sebanyak 36 responden dengan presentase $(45,6)$, kategori sedang sebanyak 25 responden dengan presentase $(31,6 \%)$ dan kategori kurang sebanyak 18 responden dengan presetase $(22,8 \%)$

\section{PEMBAHASAN}

Berdasarkan tabel 1 distribusi frekuensi pengetahuan tentang protokol kesehatan pada pengunjung Praktik Mandiri Bidan Swasta di Desa Rajagaluh Kidul tahun 2021, responden dengan kategori baik sebanyak 45 responden dengan presentase ( $57,0 \%$ ) pengunjung bisa dikatakan pengetahuannya baik dilihat dari tingkat pengetahuannya yaitu pengunjung dapat memahami, mengetahui sampai dengan mengaplikasikannya atau menerapkannya, apa saja protokol kesehatan yang harus diterapkan oleh pengunjung tersebut dan pengunjung yang berpengetahuan baik juga bisa dilihat dari salah satu faktor yaitu faktor pendidikan artinya semakin tinggi tingkat pendidikannya maka semakin mudah dalam menerima informasinya, selanjutnya kategori cukup sebanyak 22 responden dengan presentase $(27,8 \%)$ dilihat dari tingkat 
pengetahuannya. pengunjung hanya dapat mengetahui dan memahami protokol kesehatan tersebut, adapun beberapa faktor yang mempengaruhinya yaitu salah satunya faktor lingkungan dan sosial budaya artinya yaitu sosial budaya mempengaruhi sikap seseorang menerima informasi yang diberikan seperti protokol kesehatan, dan kategori kurang sebanyak 12 responden dengan presetase $(15,2 \%)$ artinya disini bisa dilihat dari tingkat pengetahuannya, pengunjung hanya dapat mengetahui tentang protokol kesehatan saja, adapun beberapa faktor yang mempengaruhi pengetahuan pengunjung yaitu salah satunya usia, adanya peningkatan usia pengetahuan tentang protokol kesehatan akan menurun (Ta'adi, dkk, 2019).

Menurut Notoatmodjo (2014) bahwa pengetahuan adalah hasil tahu seseorang terhadap objek melalui indera yang dimilikinya. Pengetahuan tiap orang akan berbeda-beda tergantung dari bagaimana penginderaannya masingmasing terhadap objek atau sesuatu. Penginderaan terjadi melalui indera manusia, yakni indera penglihatan, pendengaran, penciuman, rasa dan raba. Sebagian besar pengetahuan manusia diperoleh melalui mata dan telinga. Menurut Notoatmodjo (2014), pengetahuan seseorang dapat dipengaruhi oleh beberapa faktor diantaranya: pendidikan, pekerjaan, umur, faktor lingkungan dan sosial budaya. Pengetahuan seseorang biasanya diperoleh dari pengalaman yang berasal dari berbagai macam sumber, misalnya; media massa, media elektronik, buku petunjuk, petugas kesehatan, media poster, kerabat dekat dan sebagainya.

Pengetahuan merupakan salah satu hal yang penting diperhatikan dalam rangka penanganan khususnya dalam transmisi penyebaran dan menekan penyebaran virus (Law, Leung \& Xu, 2020). Pengetahuan yang dimiliki ini akan mempengaruhi seseorang dalam menentukan dan mengambil keputusan terhadap suatu permasalahan yang dihadapi (Purnamasari, Ika Rahayani, 2020). Hal ini terbukti pada hasil penelitian dimana mayoritas pengunjung memiliki pengetahuan tinggi lebih patuh terhadap protokol kesehatan covid 19.

Pemerintah harus memiliki strategi tepat untuk dapat menyebarkan informasi terkait covid 19 dan pencegahannya sehingga dapat meningkatkan pengetahuan yang cenderung rendah tentang penyakit ini. Peningkatan pengetahuan masyarakat terkait covid 19 dapat mendorong masyarakat untuk patuh dalam mengikuti segala protokol kesehatan yang telah ditetapkan. Hal ini didukung oleh Ahmadi (2013) yang menyatakan bahwa seorang yang memiliki pengetahuan tentang suatu informasi, maka akan mampu menentukan dan mengambil keputusan dalam menghadapi suatu permasalahan, atau masyarakat yang memiliki pengetahuan tentang covid 19 maka akan mampu menentukan bagaimana dirinya harus berprilaku dalam menghadapi penyakit tersebut. Berdasarkan tabel 2 distribusi frekuensi kepatuhan penerapan protokol kesehatan pada pengunjung Praktik Mandiri Bidan Swasta di Desa Rajagaluh Kidul tahun 2021, responden dengan kategori tinggi sebanyak 36 responden dengan presentase $(45,6 \%)$ artinya pengunjung disini selalu mematuhi protokol kesehatan yang dipengaruhi oleh salah satu faktor yaitu tingkat pengetahuan dan tingkat pendidikannya, kategori sedang sebanyak 25 responden dengan presentase $(31,6 \%)$ pengunjung yang berkepatuhan sedang disini pengunjung terkadang mematuhi protokol kesehatan dan terkadang tidak mematuhi protokol kesehatan yang dipengaruhi oleh usia dan lingkungan sekitar dan kategori kurang sebanyak 18 responden dengan presetase $(22,8 \%)$ kepatuhan yang kurang disebabkan karena pengunjung terkadang lupa dan tidak mematuhi protokol kesehatan yang dipengaruhi oleh usia, dan pengunjung terkadang merasa protokol kesehatan yang mereka terapkan sudah merasa benar yang dipengaruhi oleh pengetahuan, pendidikan dan sikap.

Angka kasus Covid 19 di Desa Rajagaluh Kidul yang terkonfirmasi positif Covid 19 yaitu berjumlah 7 orang untuk penanganannya sendiri yaitu dengan cara terus mematuhi protokol kesehatan yang telah diterapkan dan 
terus dijalankan agar terhindar dari Covid 19 (Fajarsatu, 2020). Kepatuhan terhadap protokol kesehatan harus bisa mengimbangi kebijakan yang telah dibuat yaitu penerapan new normal, sehingga dapat meningkatkan perilaku pencegahan Covid-19 agar tidak bertambah kasus baru. Perilku pencegahan Covid-19 di Desa Rajagaluh Kidul sendiri yaitu mulai dari mencuci tangan, penggunaan masker, tidak melakukan kontak fisik, meningkatkan daya tahan tubuh melalui asupan nutrisi dan olahraga, menjaga jarak dan melakukan penyemprotan cairan disinfektan yang dilakukan oleh pemerintahan desa. Untuk masyarakat yang datang dari luar kota atau zona merah harap untuk melaporkan diri ke RT setempat dan didata sebagai ODP, jika selama 14 hari Isolasi diri terdapat gejala-gejala seperti pilek, batuk dan demam tinggi akan melakukan pelaporan terhadap pihak yang terkait yaitu Puskesmas. Himbauan dari pemerintahan Desa yaitu harap tenang, jangan panik, tetapi tetap waspada (Mulyadi, 2020).

Hasil penelitian ini sejalan dengan penelitian yang pernah dilakukan oleh Novi Afrianti, Cut Rahmiati (2021 ) dengan judul Faktor-Faktor Yang Mempengaruhi Kepatuhan Masyarakat Terhadap Protokol Kesehatan Covid 19. Hasil penelitian yang dilakukannya terhadap 163 responden diketahui bahwa 146 orang $(89,6 \%)$ masyarakat memiliki kepatuhan tinggi terhadap protokol kesehatan. Hal ini sama disampaikan melalui hasil survey Badan Pusat Statistik (BPS) tahun 2020 yang mencatat tingkat kepatuhan masyarakat Indonesia dalam menerapkan protokol kesehtan sudah cukup baik demi mencegah virus corona Covid 19.

Kepatuhan adalah menuruti suatu perintah atau suatu aturan (Bart,2015). Menurut Kozier (2010) Kepatuhan adalah perilaku individu (misalnya: minum obat, mematuhi diet, atau melakukan perubahan gaya hidup) sesuai anjuran terapi dan kesehatan. Tingkat kepatuhan dapat dimulai dari tindak mengindahkan setiap aspek anjuran hingga mematuhi rencana. Kepatuhan (Compliance) merupakan suatu bentuk perilaku ketaatan seseorang terhadap tujuan yang telah ditetapkan menurut
Smeth dalam Rosa (2018). Faktor - faktor yang mempengaruhi kepatuhan tergantung pada banyak faktor, termasuk pengetahuan, motivasi arti akan penilaian perilaku kepatuhan seseorang (Priyanto, 2018).

\section{KESIMPULAN}

Berdasarkan hasil penelitian tentang Pengetahuan Dan Kepatuhan Penerapan Protokol Kesehatan Pada Pengunjung Praktik Mandiri Bidan Swasta Di Desa Rajagaluh Kidul Tahun 2021 maka dapat disimpulkan bahwa tingkat pengetahuan protokol kesehatan dan kepatuhan penerapan protokol kesehatan pada pengunjung adalah sebagai berikut :

1. Tingkat pengetahuan pengunjung di Praktik Mandiri Bidan Swasta Desa Rajagaluh Kidul sebagian besar memiliki pengetahuan yang baik mengenai Protokol Kesehatan yaitu sebesar 45 orang $(57,0 \%)$.

2. Tingkat kepatuhan pengunjung di Praktik Mandiri Bidan Swasta Desa Rajagaluh Kidul sebagian besar memiliki kepatuhan yang tinggi mengenai Penerapan Protokol Kesehatan yaitu sebesar 36 orang $(45,6 \%)$.

\section{REFERENSI}

Afrianti, N \& Rahmawati, C. 2021. Faktor-Faktor Yang Mempengaruhi Kepatuhan Masyarakat Terhadap Protokol Kesehatan Covid-19. Jurnal Ilmiah Permas: Jurnal Ilmiah STIKES Kendal. 11(1): 113-124.

Ahmadi. 2013. Kesehatan Masyarakat, Teori Dan Aplikasi. Jakarta: Raja Gafindo.

Almi. 2020. Analisis Penyebab MasyarakatTidak Patuh Pada protokol Covid-19. (Diakses pada tanggal 29 Januari 2021)

Anies, 2020. COVID-19: Seluk Beluk Corona Virus Yang Wajib Dibaca. Arruzz Media. Jogjakarta.

Atiqoh \& Devi, 2020. Hubungan Antara Pengetahuan Masyarakat Dengan Kepatuhan Menggunakan Maker Sebagai Upaya Pencegahan Penyakit Covid-19 di Ngronggah. Jurnal INFOKES Vol 10 no 1 .

Harahap, R. 2020. Karakteristik Klinis Penyakit Coronavirus 2019. Jural Penelitian Perawat Profesional. 2(3): 317-324.

http://bppsdmk.kemkes.go.id/pusdiksdmk/wpcontent/uploa ds/2018/09/Metodologi-Penelitian-Kesehatan-SC.pdf (Diakses pada tanggal 29 Januari 2021). 
https://covid19.majalengkakab.go.id/ (Diakses pada tanggal 03 Februari 2021).

https://pikobar.jabarprov.go.id/ (Diakses pada tanggal 14 Februari 2021).

http://repo.poltekkesbandung.ac.id/1220/9/BAB/2520III.p df(Diakses pada tanggal 29 Januari 2021).

https://www.korancirebon.com/2020/03/pemdes-rajagaluhkidul-semprotkan. (Diakses pada tanggal 03 Juni 2021).

Indriyanti, D. 2020. ImplementasI Protokol Kesehatan Pada Petugas Puskesmas Di Masa Pandemi Puskesmas Cileungsi Kabupaten Bogor. Jurnal Inovasi Aparatur. 2(2): 235-246.

Jubaedah, A. 2020. Situasi Pelayanan Kebidanan di Indonesia Dalam Masa Pandemi Covid-19. (Diakses pada tanggal 29 Januari 2021).

Jubaedah, H. A. and Sit, S. 2020. Tantangan Peofesi Bidan Saat Ini Dan Masa Depan. (Diakses pada tanggal 29 Januari 2021).

Kiki Gustini. 2015. Gambaran Pengetahuan Siswa Kelas IX Tentang Penyakit Menular Seksual Si SMA Negeri 24 Bandung.

Mulati, E. 2020. Peran Praktik Bidan Mandiri Dalam Pelayanan Kesehatan Reproduksi Pada Masa Pandemi Covid-19. (Diakses pada tanggal 29 Januari 2021).

Novi aprianti \& Cut Rahmiati. 2021. Faktor-Faktor Yang Mempengaruhi Kepatuhan Masyarakat Terhadap Protokol Kesehatan Covid-19. 11(1). Hal 113-124.

Notoatmodjo, S. 2018. Metodologi Penelitian Kesehatan. Jakarta: Rineka Cipta.
Nursalam. 2013. Metodologi Penelitian Ilmu Keperawatan. Edisi 3 Jakarta : Salemba Medika.

Nursalam. 2015. Metodologi Penelitian Ilmu Keperawatan Pendekatan Praktis Jakarta : Salemba Medika.

POGI.2020. Rekomendasi penanganan infeksi virus corona (covid-19) pada maternal (hamil, bersalin dan nifas). indonesia: pogi. 2020

Risma, 2016. Faktor Yang Mempengaruhi Penggunaan Intra Uterine Device (IUD) Pada Ibu Multigravida di Wilayah Kerja Puskesmas Cangkol Kota Cirebon.

Septi, M. 2019. Kemampuan Koneksi Matematis (Tinjauan Terhadap Pendekatan Pembelajaran Savi). 53(9). Pp. 1689-1699.

Sutriyanti, N. 2020. Menyemai Benih Dharma Perspektif Multidisiplin. Sulawesi Selata: Yayasan Ahmar Cendekia Indonesia.

Soekidjo Notoatmodjo. 2018. Metodologi Penelitian Kesehatan. Jakarta : Rineka Cipta.

Tim Kerja Kementrian Dalam Negri. 2013. Pedoman Umum Dalam Menghadapi Pandemi Covid-19 Bagi Pemerintah Daerah: Pencegahan, Pengendalian, Diagnosis dan Manajemen. Jurnal Of Chemical Information and Modeling, 53(9). pp. 1689-1699.

Wawan, A \& Dewi.2011. Teori dan Pengukuran Pengetahuan, Sikap, dan Prilaku Manusia. Yogyakarta: Nuha Medik 